\title{
Analysis of Safety Building Facilities as a Fire Prevention Effort at the State University of Malang's Faculty of Sports Science
}

\author{
Lingga Fitriana Sarida ${ }^{1}$, Moch. Yunus ${ }^{2}$, Sendhi Tristanti Puspitasari ${ }^{3, *}$ \\ ${ }^{1,3}$ Departement of Pubic Health, Faculty of Sports Science, Universitas Negeri Malang, East Java, Indonesia \\ ${ }^{2}$ Departement of Sport Coaching Education, Faculty of Sports Science, Universitas Negeri Malang, East Java, \\ Indonesia \\ *Corresponding author. Email: sendhi.tristanti.fik@um.ac.id
}

\begin{abstract}
A fire hazard is one of the potential hazards of Occupational Safety and Health or K3 in buildings. In high-rise buildings, escape routes are few and limited, necessitating the implementation of effective, efficient, and integrated fire prevention measures. The purpose of this study is to determine the completeness of safety building facilities, to identify and analyze the feasibility of safety building facility function, and to design efforts to optimize the functional safety building facilities in the C6 FIK UM building. This descriptive qualitative research was conducted in the C6 FIK UM building using the method of observation and document review. Building fire safety inspection observation guidelines ( $\mathrm{Pd}-\mathrm{T}-11-$ 2005-C) are used to measure the reliability value of building safety systems (NKSKB), and John Stephenson Associates Fire Training Consultants observation guidelines are used to measure the level of risk and priority of action. The findings of the research and assessment of the NKSKB of the FIK UM building received a score of 89.76 percent and were classified as good. The FIK UM building has a low to moderate risk level, and the priority actions that must be taken are engineering and administrative arrangements. The FIK UM building falls into the good category and can be considered reliable in fire prevention efforts; however, it must be tested, inspected, recorded, and repaired regulary.
\end{abstract}

Keywords: fire hazard, buildings, building reliability

\section{INTRODUCTION}

A building is defined as the physical form of construction workers who are integrated with their domicile partially or entirely above or in the ground or water, which functions as a public interest and has been determined in accordance with the fulfillment of the technical requirements of the building [1]. Buildings that are relatively safe face a variety of emergency risks, and safety is an important requirement that a building must meet [2]. Building classification can be seen from the function of building use based on the fulfillment of the level of administrative requirements, technical requirements, and functions used in planning implementation, or building changes required [3]. In order to facilitate users or visitors in activities inside the building, the completeness of facilities and infrastructure for the use of buildings and the environment must be in accordance with the needs of all age groups and conditions of physical, mental, intellectual, or sensory limitations [4].

Fire is a disaster that occurs as a result of three firerelated factors, can occur at any time and in any location, and can result in property losses as well as death [5]. Fires are classified based on their origin to aid in fire prevention and suppression efforts [6]. The compartment fire development process is divided into four stages: the initial fire stage, the fire growth stage, the full fire development stage, and the fire recession stage [7]. Fire prevention is an anticipatory and preventive effort to prevent fires or to reduce the risk of fires, and fire prevention is an effective and efficient effort and rescue action when a fire occurs [8].

In one of India's college centers a fire broke out, leaving 19 students dead and many jumping to save themselves [9]. A fire also broke out in one of Undhiksa Singaraja's laboratories, which was caused by an electrical short circuit and required the assistance of three 
firefighters to extinguish [10]. The forest product engineering laboratory at the University of Palangka Raya (UPR) caught fire due to an electrical short on the building's roof, causing material losses of up to Rp. 250,000,000.00 [11]. Between January 1st, 2020 and April 9th, 2020, Indonesia experienced 161 fire incidents, which resulted in 5 people being killed or missing, 2 people being injured, 417 people being displaced and affected by material losses, 247 houses being heavily damaged, 3 houses being moderately damaged, 21 houses being slightly damaged, and 4 educational facilities being damaged In February 2019, a fire broke out in the electricity transformer of the Syaiful Anwar Hospital in Malang City, causing material losses of more than 6 billion rupiahs [13]. According to research conducted at PT PJB UP Brantas Malang, it is necessary to prevent and overcome fires in all places in order to avoid fires that can cause large losses [14].

Fires can occur for a variety of reasons, but they can be divided into two categories: human error and failure of the building's "engineering" system. Both aspects function well during planning, implementation, construction, and operations, as well as post-occupancy [15]. System failure is more prevalent in Indonesia, particularly the failure of the electrical system in buildings, such as an electrical short circuit [16]. The building has a potential risk of Occupational Safety and Health hazards, and the Faculty of Sports Science, Universitas Negeri Malang building is one of the buildings that have social and cultural functions because there are humans who carry out social and cultural activities such as lectures and work. The building of the Faculty of Sports Science, Universitas Negeri Malang, or FIK UM, has eight floors and was inaugurated on January 7, 2020, making the FIK UM building a newly operational building. Researchers' preliminary observations revealed that each floor had an APAR that was placed separately and could be reached by building occupants and users. At the end of the hall on each floor, there are two hydrants. Each floor has two evacuation routes, one on the east and one on the west sides of the building, as well as two emergency exits and two emergency stairs that serve as evacuation routes. The emergency door is easy to open, and the emergency stairs are not blocked by anything, but the condition of the heavy doors and the emergency stairs that have not been cleaned can cause other health problems; there is also an elevator next to the emergency stairsSprinklers and heat detectors are also installed on each floor, both inside and outside the lecture hall. The FIK UM building does not own any notification media, both audio and visual, in the event of a disaster.

According to the findings of a brief interview conducted by the researcher on March 30, 2020, with the Head of the General and Finance Sub-Section FIK UM, the FIK UM building has corridors, building corridors located in front of the building, emergency stairs, emergency exits, exit directions, but lacks emergency lighting, assembly points, evacuation maps, and lightning rods. FIK UM has to have excellent and comprehensive safety buildings facilities in both fire-protection and lifesaving installations, as the building is an 8-story building used by many every day because of gym room, library, administration rooms, seminar rooms, lecture halls, laboratory rooms, and hall areas are available. According to observations and preliminary interviews conducted by researchers, the FIK UM building is not optimal in meeting the safety building facilities, which can result in unwanted events and endanger all parties.

Based on the data and conditions described above, this study was carried out to identify safety building facilities in the Faculty of Sports Science, Universitas Negeri Malang, also known as FIK UM, for the prevention and mitigation of hazards that may occur at any time based on existing safety standards. The researcher recommends repairs and enhancements to building safety facilities in the most recent update to this research

\section{METHOD}

This is a qualitative descriptive study by examining the current safety and infrastructure facilities of the UM FIK building. Data from document review, observation, and documentation have been obtained in this study. The instrument used was an observation guide sheet from the Ministry of Public Works' Research and Development Agency for Public Works Pd-T-11-2005-C, and the assessment is carried out by assessing the level of reliability of the sub-components using the assessment parameters listed in table 1 . The researcher also used John Stephenson Associates Fire Safety Training Consultants' observation guidelines, which evaluate risk levels based on the risks matrix, to determine the risk level in the research area with the assessment parameters in Table 2. This study was subjected to an ethical review, which is housed at Poltekkes, Ministry of Health, Malang, and bears the certificate No. Reg.: 037 / KEPKPOLKESMA/2021. The study was carried out at the Faculty of Sports Science, State University of Malang.

Table 1. Fire Audit Assessment Level

\begin{tabular}{|c|c|c|}
\hline Score & Suitability & Reliability \\
\hline$>80-100$ & in accordance with the requirements & Mooderate (M) \\
\hline $60-80$ & $\begin{array}{c}\text { Installed, but a small portion of the installation does not meet the } \\
\text { requirements }\end{array}$ & Poor (P) \\
\hline$<60$ & Not suitable at all & \\
\hline
\end{tabular}


Table 2. Risk Assessment and Priority of Action

\begin{tabular}{|l|l|}
\hline \multicolumn{1}{|c|}{ Risk Level } & \multicolumn{1}{c|}{ Priority of Action } \\
\hline Extremely Dangerous & The action must be completed immediately (Strongly Required) \\
\hline High Risk & The action must be completed within three months (Mandatory) \\
\hline Moderate Risk & The action must be completed within six months (Highly Recommended) \\
\hline Low Risk & The action must be completed within 12 months (Recommended) \\
\hline
\end{tabular}

\section{RESULTS AND DISCUSSION}

\subsection{Completeness of FIK UM Building Fire Safety Facilities}

The FIK UM building has safety building facilities that contribute to the building's dependability. The FIK UM building's safety building facilities almost meet the requirements for completeness of facilities to prevent fire. The NKSKB results obtained by the FIK UM buildings are 89.76 percent, placing them in the good category. Although there is one sub-component that falls into the poor category, the completeness of the site facilities available in the FIK UM building is in the good category. The FIK UM building has good rescue facilities.

\subsubsection{Site Equipment}

The site's completeness on the FIK UM building is rated "G" (Good) with a total score of 21.87 percent out of a possible 25 percent. The fulfillment of the assessment criteria contained in Pd-T-11-2005-C has benefits for the FIK UM building, specifically the ability to determine which sub-components do not meet the assessment criteria. The sub-components of water sources, the environmental roads, and building distance are categorized as 'G' (Good), and the sub component of the yard hydrant is categorized as 'P' (Poor). The water source sub-component in the FIK UM building has received a "G" (Good) category with a value of 6.75 percent and can be an advantage because the fulfillment of the criteria for the water source sub-component is in accordance with the requirements. The ground reservoir in the FIK UM building has a volume of $60 \mathrm{~m}$ and two roof tanks with a volume of $8 \mathrm{~m}^{3}$ each. The environmental road sub-component in the FIK UM building met the applicable requirements with a value of 5.62 percent and is rated good. Environmental roads also play an important

Table 3. Site Completion Component Assessment role in preventing fires. Environmental road conditions with a width of 5.8 meters are available in FIK UM, as are paving blocks. The sub-component of building distance in the FIK UM building met the requirements and received a score of 5.75 percent, placing it in the good category and providing protection against fire hazards. With a distance of 15 meters, the Al-Hikmah UM mosque is the closest building to the FIK UM building. A sufficient distance between buildings can reduce the risk of fire hazards and slow the spread of fires.

In the FIK UM construction, the sub-component of the yard hydrant is in the "P" category (Poor) at a value of $3.75 \%$ as the red hydrant box does not feature any equipment containing the words "HYDRANT" in white. In addition, the yard hydrant box had been unlocked and filled with rocks. The FIK UM building's yard hydrant is not ready for use because the equipment is either incomplete or empty, and the water supply is unknown. A lack of yard hydrants can impede the firefighting process and increase losses in the event of fire since there is no early-stage fire extinguishing, allowing the fire to spread swiftly. The assessment of the completeness of the site components in the FIK UM building received a nearly perfect score, with the exception of one subcomponent, namely the yard hydrant sub-component. Components of site completeness that almost always yield reliable results can help to prevent and reduce fire hazards, as demonstrated by research conducted at Ayola First Point [17] which received a score of 23.28 percent. The site completeness component was also researched at the Pesonna Hotel Pekanbaru [18] which received a score of 21.35 percent, and at the Central Java Police Building, which received a score of 23.85 percent [2].

\begin{tabular}{|c|l|c|c|c|c|c|}
\hline No. & KSKB / SUB KSKB & $\begin{array}{c}\text { Ranting } \\
\text { Results }\end{array}$ & $\begin{array}{c}\text { Standard of } \\
\text { Evaluation }\end{array}$ & Quality & Condition value & Total Value \\
\hline I. & \multicolumn{1}{|c|}{ Site Equipment } & $\mathbf{2 5}$ & & 6,75 \\
\hline 1. & Water Sources & B & 100 & 27 & 27 & 5,62 \\
\hline 2. & Environmental Roads & B & 90 & 25 & 22,5 & 5,75 \\
\hline 3. & $\begin{array}{l}\text { Distance between } \\
\text { Buildings }\end{array}$ & B & 100 & 23 & 23 & \\
\hline
\end{tabular}




\begin{tabular}{|c|c|c|c|c|c|c|}
\hline No. & KSKB / SUB KSKB & $\begin{array}{c}\text { Ranting } \\
\text { Results }\end{array}$ & $\begin{array}{c}\text { Standard of } \\
\text { Evaluation }\end{array}$ & Quality & Condition value & Total Value \\
\hline 4. & Yard Hydrant & K & 60 & 25 & 15 & 3,75 \\
\hline & & & & & Total & 21,87 \\
\hline
\end{tabular}

\subsubsection{Rescue Facilities}

Rescue facilities in FIK UM buildings are rated "G" (Good) with a value of 23.17 percent out of a possible 25 percent. When an emergency occurs, a good rescue facility can carry out the evacuation process for building residents and visitors, because the main step in the event of a fire is to save the occupants or humans who are on the scene [19]. With a value of 8.55 percent, the sub-components of the egress available in the FIK UM building met the requirements of Pd-T-11-2005-C. The FIK UM building has three exits, two of which are emergency stairs with fireproof doors and one of which is a ladder used for daily activities. Exit signs are also installed at each exit, and there are no obstacles, despite the fact that two of them are a little dusty due to infrequent use. The exit to the FIK UM building is also unobstructed, leading to an open space. There are no other safety signs on the FIK UM building, only an "exit" sign on the ceiling that leads to the emergency stairs or stairs used for daily activities. With a value of 7.87 percent, the fulfillment of the criteria for the exit construction sub-component is included in the "G" (Good) category.

The width of the exit construction in the FIK UM building is four meters, which meets the assessment criteria that the width of the exit construction be at least two meters [20]. The FIK UM building stands 34.25 meters tall and does not require a helicopter pad. The building must have a minimum height of 60 meters in order to have a helicopter pad [21]. As a result, there was no evaluation of the helicopter pad. The assessment of the components of the FIK UM building's life-saving facilities, which is in the good category, is consistent with the research conducted at the Bekasi District Hospital, which has a score of 23.25 percent and is in the good category [22]. The UNY Hotel research did not evaluate the subcomponents of its helicopter pads because there was no helicopter pad at the UNY Hotel and the rescue facility component achieved a score of 25 percent [23]. Furthermore, research carried out at the Pekanbaru Ayola First Point Hotel has not assessed the sub-component of the fire field and obtained a score of 23.7 percent. [17].

Table 4. Assessment of Rescue Facilities Components

\begin{tabular}{|c|l|c|c|c|c|c|}
\hline No. & KSKB / SUB KSKB & $\begin{array}{c}\text { Rating } \\
\text { Results }\end{array}$ & $\begin{array}{c}\text { Standard of } \\
\text { Evaluation }\end{array}$ & Quality & Condition Value & Total Value \\
\hline I. & Rescue Facilities & & $\mathbf{2 5}$ & & \\
\hline 1. & Exit & B & 90 & 38 & 34,2 & 12,05 \\
\hline 2. & Exit Construction & B & 90 & 35 & 31,5 & 11,12 \\
\hline 3. & Helicopter Pad & - & - & 27 & - & - \\
\hline & & & & & Total & $\mathbf{2 3 . 1 7}$ \\
\hline
\end{tabular}

\subsection{FIK UM Building Active Fire Protection System}

The active protection system available in the FIK UM buildings as a whole is in the good category, with a score of 21.34 percent out of 24 percent, though there are several sub-components that fall into the "M" (Moderate) and "P" (Poor) categories. The active protection system components include 13 sub-components that were being evaluated. The sub-components for detection and alarm, emergency light, and operating control room fall within the moderate category, while the sub-component fire lift is in the poor category. With an assessment result of 1.53 percent of the maximum value of 1.92 percent, the detection and alarm sub-components are in the moderate category. Detection and alarm systems have been installed in the FIK UM building, but they have never been tested. The siamese connection sub-components available in FIK UM buildings are in the good category, with a value of 1.92 percent from 1.92 percent. There is only one Siamese connection, which is visible to firefighters and is located in front of the building. The sub-components of fire extinguisher or APARs in FIK UM buildings are in the good category, with a value of 1.72 percent compared to 1.92 percent. Fire extinguishers in the FIK UM building used dry chemical. Fire extinguishers located on each floor. The distance between fire extinguishers is 5-15 meters, and the distance between fire extinguishers and the floor is 1.2 meters, but each fire extinguisher has no maintenance label.

The FIK UM building's sub-component of building hydrants is in the good category, with a value of 1.92 percent from 1.92 percent. There is a hose with a length of 30 meters and a diameter of $39 \mathrm{~mm}$, so the facilities in 
the building hydrant sub-component is complete. Building hydrants are located on the west and east sides of the FIK UM building, in easily accessible locations. The building hydrant is easily identified by the red box and the words "HYDRANT". The sprinkler subcomponent in the FIK UM building is in the good category, with a value of 1.72 percent of 1.92 percent. In the FIK UM building, the distance between sprinklers is 4.6 meters, with the same number of sprinklers on each floor. The sub-component of the FIK UM building's overflow extinguishing system is in the good category, with a value of 1.68 percent from 1.68 percent. The FIK UM building's smoke control sub-component and smoke detector sub-component are both in the good category, with a smoke control sub-component value of $1.92 \%$ from $1.92 \%$. The smoke detection and exhaust subcomponents in the FIK UM building are both good, with a smoke detection sub-component value of 1.72 percent from 1.92 percent and a smoke exhaust sub-component value of 1.42 percent from 1.68 percent. The detectors are located on every floor, including the nutrition laboratory and the kitchen, and are in good working order. Smoke disposal in the FIK UM building is accomplished through the use of fans located in each room; however, the location of the smoke reservoir in the FIK UM building is unknown. Because the FIK UM building lacks a fire elevator, the sub-component of the fire lift is categorized as Poor, with a value of $1 \%$ as opposed to $1.68 \%$.
The sub-component of emergency lighting in the FIK UM building falls into the moderate category, with a value of $1.53 \%$ from $1.92 \%$. The FIK UM building did not yet have emergency lighting, but there is lighting from lamps in general on the emergency stairs. The emergency power sub-component in the FIK UM building is in the good category, with a value of 1.92 percent from 1.92 percent. Emergency power is supplied by a generator located to the west of the building, and cable installation is carried out using SNI-compliant cables. The sub-component of the FIK UM building's operation control room is in the moderate category, with a value of $1.34 \%$ of $1.68 \%$. The available device in the operation control room is simple device, i.e. a CCTV monitor. The evaluation of the active protection system components in the FIK UM building is consistent with research conducted at the 5-story UNY Hotel Yogyakarta, where the results obtained for the evaluation of the active protection system are 20.04 percent from 24 percent [23]. The active protection system at the Pekanbaru BRI Tower Building received a score of 22.77 percent [24]. Ayola First Point Hotel Pekanbarus research yielded a value of 19.40 percent after evaluating 12 sub-components [17].

Table 5. Active Protection System Component Assessment

\begin{tabular}{|c|c|c|c|c|c|c|}
\hline No. & KSKB / SUB KSKB & $\begin{array}{l}\text { Rating } \\
\text { Results }\end{array}$ & $\begin{array}{l}\text { Standard of } \\
\text { Evaluation }\end{array}$ & Quality & Condition Value & Total Value \\
\hline I. & \multicolumn{3}{|l|}{ Active Protection } & 24 & & \\
\hline 1. & Alarm and Detection & $\mathrm{C}$ & 80 & 8 & 6,4 & 1,53 \\
\hline 2. & Siamese connection & $\mathrm{B}$ & 100 & 8 & 8 & 1,92 \\
\hline 3. & Fire Extinguisher & B & 90 & 8 & 7,2 & 1,72 \\
\hline 4. & Building Hydrant & $\mathrm{B}$ & 100 & 8 & 8 & 1,92 \\
\hline 5. & Sprinkler & $\mathrm{B}$ & 90 & 8 & 7,2 & 1,72 \\
\hline 6. & $\begin{array}{l}\text { Overflow Extinguishing } \\
\text { System }\end{array}$ & B & 100 & 7 & 7 & 1,68 \\
\hline 7. & Smoke Controller & $\mathrm{B}$ & 100 & 8 & 8 & 1,92 \\
\hline 8. & Smoke Detector & $\mathrm{B}$ & 90 & 8 & 7,2 & 1,72 \\
\hline 9. & Smoke Exhaust System & B & 85 & 7 & 5,9 & 1,42 \\
\hline 10. & Fire Lift & $\mathrm{K}$ & 60 & 7 & 4,2 & 1 \\
\hline 11. & Emergency Light & $\mathrm{C}$ & 80 & 8 & 6,4 & 1,53 \\
\hline 12. & Emergency Power & B & 100 & 8 & 8 & 1,92 \\
\hline \multirow[t]{2}{*}{13.} & Operation Control Room & $\mathrm{C}$ & 80 & 7 & 5,6 & 1,34 \\
\hline & & & & & Total & 21,34 \\
\hline
\end{tabular}

\subsection{FIK UM Building Passive Fire Protection System}

Based on the evaluation of three sub-components, the passive protection system in the FIK UM building as a whole falls into the good category, with a value of 23.38 percent out of a possible 26 percent. The structural fire resistance sub-component received a value of 8.42 percent and was classified as good. The FIK UM building is classified as type $\mathrm{C}$ due to its $2400 \mathrm{~m}^{2}$ building area and function as a socio-cultural building. The subcomponent of the FIK UM space compartment is in the good category with an overall value of $7.48 \%$. The compartmentalization of the space is provided with 
sprinklers, fire engine entrances, and an automatic smoke exhaust system. Fire engines can pass through the width of the road in front of the building, but not to the sides or back of the building. With a value of 7.48 percent, the aperture protection sub-component is rated as good.

The researcher's findings are consistent with the study titled "Evaluasi Penerapan Sistem Keselamatan Kebakaran Pada Gedung-Gedung Umum di Kota Payakumbuh" with a value for the passive protection system, namely in the hospital building (A1), of 22.6 percent, and a score of 21.01 percent for office buildings [21]. Research conducted at the Bekasi District Hospital obtained a score of $24.34 \%$ for its passive protection system [22]. Passive protection system assessment was also conducted at Pesonna Hotel Pekanbaru, which received a perfect score of 26 percent [18]. The total KSKB's quality is 26 percent, and the KSKB's quality for the FIK UM building is 23.38 percent, making it nearly perfect. This demonstrates that the building's reliability value is in the good category and in accordance with applicable regulations.

Table 6. Passive Protection System Component Assessment

\begin{tabular}{|c|l|c|c|c|c|c|}
\hline No. & KSKB / SUB KSKB & $\begin{array}{c}\text { Rating } \\
\text { Results }\end{array}$ & $\begin{array}{c}\text { Standard } \\
\text { of } \\
\text { Evaluation }\end{array}$ & Quality & Condition Value & Total Value \\
\hline I. & Passive Protection & & $\mathbf{2 6}$ & & 8,42 \\
\hline 1. & $\begin{array}{l}\text { Fire Resistance of } \\
\text { Building Structures }\end{array}$ & B & 90 & 36 & 32,4 & 7,48 \\
\hline 2. & Space Compartment & B & 90 & 32 & 28,8 & 7.48 \\
\hline 3. & Aperture Protection & B & 90 & 32 & 28,8 & $\mathbf{2 3 , 3 8}$ \\
\hline
\end{tabular}

\subsection{Prevention and Control of Fire Hazards with Hierarchy Of Control}

Recommendations made by the Ministry of Public Works' Research and Development Center (Pd-T-112005-C) based on an 89.76 percent assessment are periodic inspections, periodic maintenance/maintenance, and repairs included in the main recommendations with the goal of increasing sub-components with less or sufficient condition to be in good condition. The advice is based on the building fire safety inspection recommendations (Pd-T-11-2005-C) [25]. According to the findings of the investigation, which was conducted using the observation criteria of John Stephenson Associates Fire Safety/Training Consultants, the FIK UM building has a medium risk level and a low danger level. It is highly suggested to take activities that must be completed within the next six months to carry out facility modifications or fulfill facility requirements at the moderate risk level. The low degree of risk is expected to conduct activities that must be completed within the next 12 months in completing requirements and repairing facilities. [26].

A hierarchy of control can be used to control and prevent fire hazards because it can minimize or reduce the amount of risk that exists to the lowest level of danger by elimination, substitution, engineering, administrative arrangements, and PPE [27]. Engineering and administrative arrangements are efforts to manage and prevent hazards that can be carried out in FIK UM buildings based on the hierarchy of control. Priority actions in the FIK UM building must be accomplished within the next 6-12 months as well. The control intends to ensure security and safety for FIK UM building users.

Control of engineering in FIK UM buildings, specifically the provision of a smoking space; Provision of smoking area facilities; Protection against cable lines Putting up lightning rods or labeling lightning rods; Decide on a site for the assembly point area; Specifies an alternative meeting location. This control is suggested for prevention emergency efforts and can contribute to reducing losses.

Controlling administrative arrangements in the FIK UM building can be accomplished by ensuring that a risk assessment has been performed in the FIK UM building and producing a risk assessment document archive. Monitoring, testing, and inspection of the current facilities in the FIK UM building on a regular basis; If there is a modification in the building, conduct a risk assessment review procedure on a regular basis. Maintain documents or archives pertaining to routine testing of installations and facilities. Conducting simulations or demonstrations of dangers at the FIK UM building; Simulations pertaining to basic fire protection actions are being carried out. Make a safety briefing warning about emergency evacuation procedures; Carry out emergency evacuation exercises Create emergency evacuation procedures in writing; Make a personal emergency escape plan; Selection or appointment of personnel capable of performing their tasks in the case of a fire; Plan for emergency evacuation training. Conduct environmental risk assessments in the event of a fire; Making K3 signs such as those for meeting locations, 
smoking zones, escape routes, pictograms, and emergency evacuation posters.

\section{CONCLUSION}

Based on the findings of the research, it is possible to conclude that the safety building facilities in the FIK UM building are complete, based on the building reliability assessment. Almost all sub-components are met and fall into the moderate to the good category, with the exception of two, which fall into the poor category: the fire lift sub-component and the yard hydrant subcomponent. Based on the building reliability assessment, the eligibility of the safety building facility function in the FIK UM building is included in the good category because almost all sub-components meet the requirements during the assessment. The results of the assessment of the site equipment sub-components are good, the rescue facilities sub-components are in the moderate category, the active protection system subcomponents are good, and the passive protection system sub-components are good. Efforts to optimize the FIK UM building are required, including efforts to control engineering and administrative arrangements.

\section{AUTHORS' CONTRIBUTIONS}

LFS: concept and design the study, data collection, data analysis, writing the manuscript; MY \& STP: validation, writing-review, supervision.

\section{ACKNOWLEDGMENTS}

We would like to thank the Head of ULP Universitas Negeri Malang, and all parties who helped with the implementation of this research so that researchers could complete it properly.

\section{REFERENCES}

[1] Peraturan Pemerintah Nomor 35 Tahun 2005, Peraturan Pemerintah RI Nomor 35 Tahun 2005 Tentang Peraturan Pelaksanaan Undang Undang Nomor 28 tahun 2002 Tentang Bangunan Gedung, no. 1. Indonesia, 2005, pp. 1-5.

[2] T. H. Gultom, B. Kurniawan, and D. Lestantyo, "Analisis Keandalan Sistem Keselamatan Bangunan Sebagai Proteksi Kebakaran Pada Gedung Polda Jawa Tengah," J. Kesehat. Masy., vol. 6, no. 5, pp. 643-647, 2018.

[3] Menteri Pekerjaan Umum, Peraturan Menteri Pekerjaan Umum Nomor: 29/PRT/M/2006 Tentang Pedoman Persyaratan Teknis Bangunan Gedung. Indonesia, 2006, pp. 1-107.

[4] Menteri Pekerjaan Umum dan Perumahan Rakyat, Peraturan Menteri Pekerjaan Umum dan Perumahan Rakyat Republik Indonesia Nomor 14/PRT/M/2017 Tentang Persyaratan
Kemudahan Bangunan Gedung. Indonesia, 2017, pp. 1-36.

[5] S. W. Mustika, R. S. Wardani, and D. B. Prasetio, "Penilaian Risiko Kebakaran Gedung Bertingkat," J. Kesehat. Masy. Indones., vol. 13, no. 1, pp. 1825, 2018.

[6] D. Kustono, Solichin, and A. Martiningsih, Keselamatan dan Kesehatan Kerja. Malang: Aditya Media Publishing, 2015.

[7] Y. Chen, P. Wang, and X. Liu, "Numerical Study on Suppression of Post-flashover Compartment Fire by Using Water Mist," in 2019 9th International Conference on Fire Science and Fire Protection Engineering, ICFSFPE 2019, 2019, doi: 10.1109/ICFSFPE48751.2019.9055792.

[8] I. Bastian, Akuntansi Sektor Publik Suatu Pengantar. Jakarta: Penerbit Erlangga, 2013.

[9] N. R. Michico, "19 Mahasiswa Tewas akibat Kebakaran di Gedung Universitas India," inews, 2019.

[10] D. B. Raharjo, "Terdengar Suara Ledakan di Kampus Undiksha Singaraja, Ruangan Lab Terbakar," Suara, 2020.

[11] Dodi, "Laboratorium di UPR Terbakar, Kerugian Ditaksir Ratusan Juta | Radar Sampit," Radar Sampit, 2020.

[12] Data Informasi Bencana Indonesia, "Data Informasi Bencana Indonesia Tahun 2005-2019,' $B N P B, \quad 2020 . \quad$ [Online]. Available: http://bnpb.cloud/dibi/tabel3b. [Accessed: 19Sep-2020].

[13] BPBD, "[Update] Sepanjang 2019, 119 Bangunan Rusak Akibat Bencana," BPBD Kota Malang, 2020. [Online]. Available: https://bpbd.malangkota.go.id/2020/01/01/sepanj ang-2019-114-bangunan-rusak-akibat-bencana/. [Accessed: 19-Sep-2020].

[14] R. A. Kowara and T. Martiana, "Analisis Sistem Proteksi Kebakaran sebagai Upaya Pencegahan dan Penanggulangan Kebakaran (Studi di PT. PJB UP Brantas Malang),"J. Manaj. Kesehat. Yayasan Dr. Soetomo, vol. 3, no. 1, pp. 70-85, 2017.

[15] H. Sufianto and A. R. Green, "Urban Fire Situation in Indonesia," Fire Technol., vol. 48, no. 2, pp. 367-387, 2012, doi: 10.1007/s10694-0110226-9.

[16] H. Sufianto, A. M. Nugroho, and M. S. Aditama, "Framework Tanggap Bencana Kebakaran Gedung Kampus," J. Arsitek dan Perkota. “KORIDOR,” vol. 09, no. 01, pp. 1-8, 2015.

[17] B. Wulandari and R. Trikomara, "Analisis Keandalan Sistem Proteksi Kebakaran Pada 
Bangunan Ayola First Point Hotel Pekanbaru," Jom FTEKNIK, vol. 5, no. 1, pp. 1-9, 2018.

[18] E. Oktareza and R. T. K. Iriana, "Keandalan Sistem Proteksi Kebakaran Pada Gedung (Studi Kasus : Hotel Pesona Pekanbaru)," Jom FTEKNIK, vol. 5, no. 2, pp. 1-8, 2018, doi: 10.30853/filnauki.2018-11-2.39.

[19] A. Pratama, "Perancangan Sarana Penyelamat Diri dan Kebutuhan Apar pada Darurat Kebakaran Di Kantor Kesehatan Pelabuhan Kelas II Balikpapan,” Indones. J. Occup. Saf. Heal., vol. 5, no. 1, pp. 21-30, 2016.

[20] D. A. Hidayat, Suroto, and B. Kurniawan, "Evaluasi Keandalan Sistem Proteksi Kebakaran Ditinjau Dari Sarana Penyelamatan Dan Sistem Proteksi Pasif Kebakaran Di Gedung Lawang Sewu Semarang," J. Kesehat. Masy., vol. 5, no. 5, pp. 134-146, 2017.

[21] Y. Mareta and B. Hidayat, "Evaluasi Penerapan Sistem Keselamatan Kebakaran Pada GedungGedung Umum Di Kota Payakumbuh," J. Rekayasa Sipil, vol. 16, no. 1, p. 65, 2020, doi: 10.25077/jrs.16.1.65-76.2020.

[22] M. L. Sari and T. Sukwika, "Sistem Proteksi Aktif Dan Sarana Penyelamatan Jiwa Dari Kebakaran Di RSUD Kabupaten Bekasi," J. Ilmu Kesehat. Bhakti Husada Heal. Sci. J., vol. 11, no. 2, pp. 190-203, 2020, doi: 10.34305/jikbh.v11i2.184.

[23] M. H. Zulfiar and A. Gunawan, "Evaluasi Sistem Proteksi Kebakaran pada Bangunan Hotel UNY 5 Lantai," Semesta Tek., vol. 21, no. 1, pp. 65-71, 2018, doi: 10.18196/st.211212.

[24] R. Amtria, H. Taufik, and R. Trikomara, "Analisis Keandalan Sistem Proteksi Kebakaran Pada Gedung Menara BRI Pekanbaru," J. Sainstek STT Pekanbaru, vol. 08, no. 1, pp. 1-6, 2020.

[25] Puslitbang Kementrian Pekerjaan Umum, "Pd-T11-2005-C Pemeriksaan Pemeriksaan keselamatan kebakaran bangunan gedung," 2005.

[26] J. Stephenson, "Fire Risk Assessment Report Dale Building City Campus Chester Road," Sunderland, 2010.

[27] G. Soputan, B. Sompie, and R. Mandagi, "Manajemen Risiko Kesehatan Dan Keselamatan Kerja (K3) (Study Kasus Pada Pembangunan Gedung Sma Eben Haezar)," J. Ilm. Media Eng., vol. 4, no. 4, p. 99095, 2014. 